\title{
Bibliography of printed works cited
}

J. Alexander and P. Binski, eds, The Age of Chivalry: Art in Plantagenet England, 12001400, London, 1987.

J. A. Alford, 'Richard Rolle and related works', in Middle English Prose: a Critical Guide to Major Authors and Genres, ed. A. S. G. Edwards, New Brunswick, N.J., 1984, pp. 35-60.

H. E. Allen, Writings Ascribed to Richard Rolle, Hermit of Hampole, and Materials for his Biography, Modern Language Association of America, Monograph Series, III, New York and London, 1927.

J. D. Alsop, 'Religious preambles in early modern English wills as formulae', Journal of Ecclesiastical History, XL, 1989, pp. 19-27.

C. A. J. Armstong, England, France, and Burgundy in the Fifteenth Century, London, 1983.

M. Aston, Lollards and Reformers: Images and Literacy in Late Medieval England, London, 1984 .

C. W. Atkinson, Mystic and Pilgrim: the Book and the World of Margery Kempe, Ithaca and London, 1983.

R. F. Atkinson, Knowledge and Explanation in History: an Introduction to the Philosophy of History, London and Basingstoke, 1978.

J. H. Baker, ed., The Notebook of Sir John Port, Selden Society, CII, 1986.

A. T. Bannister, ed., Registrum Caroli Bothe, Episcopi Herefordensis, A.D. MDXVIMDXXXV, Canterbury and York Society, XXVIII, 1921.

A. T. Bannister, 'Visitation returns of the diocese of Hereford in 1397', English Historical Review, XLIV, 1929, pp. 279-89, 444-53, XLV, 1930, pp. 92-101, 444-63.

P. H. Barnum, ed., Dives and Pauper, Early English Text Society, original ser., CCLXXV, CCLXXX, 1976-80.

A. Barratt, 'Works of religious instruction', in Middle English Prose: a Critical Guide to Major Authors and Genres, ed. A. S. G. Edwards, New Brunswick, N.J., 1984, pp. $412-32$.

C. M. Barron, 'The parish fraternities of medieval London', in The Church in PreReformation Society, ed. C. M. Barron and C. Harper-Bill, Woodbridge, 1985, pp. 1337.

N. L. Beaty, The Craft of Dying: a Study in the Literary Tradition of the Ars moriendi in England, Yale Studies in English, CLXXV, New Haven, 1970.

C. Beaune, The Birth of an Ideology: Myths and Symbols of Nation in Late-Medieval France, Berkeley, Los Angeles and Oxford, 1991.

S. Beckwith, 'A very material mysticism: the medieval mysticism of Margery Kempe', in Medieval Literature: Criticism, Ideology, and History, ed. D. Aers, New York, 1986, pp. 34-57.

S. G. Bell, Medieval women book owners: arbiters of lay piety and ambassadors of culture', in Sisters and Workers in the Middle Ages, ed. J. M. Bennett et al., Chicago and London, 1989, pp. 135-61 (also in Women and Power in the Middle Ages, ed. M. Erler and M. Kowaleski, Athens, Ga., and London, 1988, pp. 149-87). 
H. S. Bennett, English Books and Readers, 1475 to 1557, 2nd ed., Cambridge, 1969.

N. H. Bennett, 'Blunham rectory accounts, 1520-39', in Hundreds, Manors, Parishes, and Churches: a Selection of Early Documents for Bedfordshire, ed. J. S. Thompson, Publications of the Bedfordshire Historical Record Society, LXIX, 1990, pp. 12469.

T. H. Bestul, 'Chaucer's Parson's Tale and the late-medieval tradition of religious meditation', Speculum, LXIV, 1989, pp. 600-19.

P. Biller, 'Words and the medieval notion of "religion", Journal of Ecclesiastical History, XXXVI, 1985, pp. 351-69.

J. Blair, 'Saint Beornwald of Bampton', Oxoniensia, XLIX, 1984, pp. 47-55.

J. Blair, 'Saint Beornwald of Bampton: further references', Oxoniensia, LIV, 1990, pp. 400-3.

N. F. Blake, ed., Middle English Religious Prose, London, 1972.

N. F. Blake, The English Language in Medieval Literature, London and New York, 1977.

N .F. Blake, 'Vernon manuscript: contents and organisation', in Studies in the Vernon Manuscript, ed. D. Pearsall, Woodbridge, 1990, pp. 45-59.

J. Bossy, 'The mass as a social institution', Past and Present, C, August 1983, pp. 29-61.

J. Bossy, 'Prayers', Transactions of the Royal Historical Society, 6th ser., I, 1991, pp. 13748.

R. Bowers, 'Obligation, agency, and laissez-faire: the promotion of polyphonic composition for the church in fifteenth-century England', in Music in Medieval and Early Modern Europe: Patronage, Sources, and Texts, ed. I. Fenlon, Cambridge, 1981, pp. $1-19$.

L. E. Boyle, 'The Fourth Lateran Council and manuals of popular theology', in The Popular Literature of Medieval England, ed. T. J. Heffernan, Tennessee Studies in Literature, XXVIII, Knoxville, Tenn., 1985, pp. 30-44.

M. T. Brady, 'The pore caitif: an introductory study', Traditio, X, 1954, 529-48.

J. R. Bray, 'Concepts of sainthood in fourteenth century England', Bulletin of the John Rylands University Library of Manchester, LXVI, 1984, pp. 40-77.

S. Brigden, London and the Reformation, Oxford, 1989.

M. G. Briscoe, 'Preaching and medieval English drama', in Contexts for Early English Drama, ed. M. G. Briscoe and J. C. Coldewey, Bloomington and Indianapolis, 1989, pp. $151-72$.

C. Burgess, "For the increase of divine service": chantries in the parish in late-medieval Bristol', Journal of Ecclesiastical History, XXXVI, 1985, pp. 46-65.

C. Burgess, "By quick and by dead": wills and pious provision in late medieval Bristol', English Historical Review, CII, 1987, pp. 837-58.

C. Burgess. 'A service for the dead: the form and function of the anniversary in late medieval Bristol', Transactions of the Bristol and Gloucestershire Archaeological Society, CV, 1987, pp. 183-211.

C. Burgess, “A fond thing vainly invented": an essay on Purgatory and pious motive in late medieval England', in Parish, Church, and People: Local Studies in Lay Religion, 1350-1750, ed. S. J. Wright, London, 1988, pp. 56-84.

C. Burgess, 'Strategies for eternity: perpetual chantries in late medieval Bristol', in Religious Belief and Ecclesiastical Careers in Late Medieval England, ed. C. Harper-Bill, Woodbridge, 1991, pp. 1-32.

C. Burgess, 'Late medieval wills and pious convention: testamentary evidence 
reconsidered', in Profit, Piety, and the Professions in Later Medieval England, ed. M. A. Hicks, Gloucester, 1990, pp. 14-33.

C. Butler, Western Mysticism: the Teaching of Augustine, Gregory, and Bernard on Contemplation and the Contemplative Life, 3rd ed., London, 1967.

Cambridge University Library MS Ff.2.38, introduction by F. McSparran and P. R. Robinson, London, 1979.

C. Carpenter, 'The religion of the gentry of fifteenth-century England', in England in the Fifteenth Century: Proceedings of the 1986 Harlaxton Symposium, ed. D. Williams, Woodbridge, 1987, pp. 53-74.

M. J. Carruthers, The Book of Memory: a Study of Memory in Medieval Culture, Cambridge Studies in Medieval Literature, X, Cambridge, 1990.

J. Catto, 'Religious change under Henry V', in Henry V, the Practice of Kingship, ed. G. Harriss, Oxford, 1985, pp. 97-115.

J. F. Chanter, 'St Urith of Chittlehampton: a study of an obscure Devon saint', Report and Transactions of the Devonshire Association for the Advancement of Science, Literature, and Art, XLVI, 1914, pp. 290-308.

F. Cheetham, English Medieval Alabasters, Oxford, 1984.

G. Cigman, 'The preacher as performer: Lollard sermons as imaginative discourse', Journal of Literature and Theology, II, 1988, pp. 69-82.

G. Cigman, 'Luceat lux vestra: the Lollard preacher as truth and light', Review of English Studies, XL, 1989, pp. 479-96.

G. Cigman, ed., Lollard Sermons, Early English Text Society, original ser. CCXCVI, 1989.

A. Clark, ed., Lincoln Diocese Documents, 1450-1544, Early English Text Society, original ser. CXLIX, 1914.

C. E. Clark-Maxwell, 'Some further letters of confraternity', Archaeologia, LXXIX, 1929, pp. 179-216.

B. Coe, Stained Glass in England, 1150-1500, London, 1981.

J. C. Colchester, ed., Wells Cathedral Fabric Accounts, 1390-1600, Wells, 1983.

J. Coleman, English Literature in History, 1350-1400: Medieval Readers and Writers, London, 1981.

M. Collins, 'A little known "Art of Dying" by a Brigittine of Syon: $A$ daily exercise and experience of death by Richard Whytford, in Dies illa: Death in the Middle Ages. Proceedings of the 1983 Manchester Colloquium, ed. J. H. M. Taylor, Vinaver Studies in French, I, Liverpool, 1984, pp. 179-93.

F. M. M. Comper, ed., The Book of the Craft of Dying, and Other Early English Tracts Concerning Death, London, 1917.

J .C. Cox, Churchwardens' Accounts from the Fourteenth Century to the Close of the Seventeenth Century, London, 1913.

A. Craiger-Smith, English Medieval Mural Paintings, Oxford, 1963.

C. Cross, 'Religious and social protest among Lollards in early Tudor England', in The Church in a Changing Society, Publications of the Swedish Society of Church History, XXX, Uppsala, 1978, pp. 71-5.

C. Cross, "Great reasoners in scripture": the activities of women lollards, 1380-1530', in Medieval Women, ed. D. Baker, Studies in Church History, Subsidia I, Oxford, 1978, pp. 359-80. 
C. Cross, 'Wills as evidence of popular piety in the reformation period: Leeds and Hull, 1540-1640', in The End of Strife: Death, Reconciliation, and Expressions of Christian Spirituality, ed. D. M. Loades, Edinburgh, 1984, pp. 44-51.

R. G. Davies, 'Lollardy and locality', Transactions of the Royal Historical Society, 6th ser., I, 1991, pp. 191-212.

J. F. Davis, 'Lollardy and the Reformation in England', Archiv fur Reformationsgeschichte, LXXIII, 1982, pp. 217-36.

N. Davis, ed., Paston Letters and Papers of the Fifteenth Century, 2 vols., Oxford, 1970.

V. Davis, 'The rule of Saint Paul, the first hermit, in late medieval England', Studies in Church History, XXII, 1985, pp. 203-14.

D. L. D'Avray, 'Papal authority and religious sentiment in the late middle ages', in The Church and Sovereignty, c. 590-1918: Essays in Honour of Michael Wilks, ed. D. Wood, Studies in Church History, Subsidia IX, Oxford, 1991, pp. 393-408.

M. Deanesly, The Lollard Bible and Other Medieval Biblical Versions, Cambridge, 1920.

M. Denley, 'Elementary teaching techniques and Middle English religious didactic writings', in Langland, the Mystics, and the Medieval English Religious Tradition: Essays in Honour of S. S. Hussey, ed. H. Phillips, Woodbridge, 1990, pp. 223-41.

C. D'Evelyn and F. A. Foster, 'Saints' legends', in A Manual of the Writings in Middle English, 1050-1500, ed. J. B. Severs, II, Hamden, Conn., 1970, pp. 410-57, 553-649.

A. G. Dickens, 'The shape of anticlericalism and the English Reformation', in Politics and Society in Reformation Europe: Essays for Sir Geoffrey Elton on his Sixty Fifth Birthday, ed. E. I. Kouni and T. Scott, Basingstoke and London, 1987, pp. 379-410.

A. G. Dickens, The English Reformation, 2nd ed., London, 1989.

R. B. Dobson, 'Mendicant ideal and practice in late medieval York', in Archaeological Papers from York presented to M. W. Barley, ed. P. V. Addyman and V. E. Black, York, 1984, pp. 109-22.

C. Dodgson, 'English devotional woodcuts of the late fifteenth century, with special reference to those in the Bodleian library', Walpole Society, XVII, 1928-9, pp. 95108.

A. I. Doyle, 'Reflections of some manuscripts of Nicholas Love's Myrrour of the blessed lyf of Jesu Christ', Leeds Studies in English, n.s. XIV, 1983, pp. 82-93.

A. I. Doyle, 'Publication by members of the religious orders', in Book Production and Publishing in Britain, 1375-1475, ed. J. Griffiths and D. Pearsall, Cambridge, 1989, pp. 109-23.

M. W. Driver, 'Pictures in print: late fifteenth- and early sixteenth-century English religious books for lay readers', in De Cella in Seculum: Religious and Secular Life and Devotion in Late Medieval England, ed. M. G. Sargent, Woodbridge, 1989, pp. 22944.

F. R. H. du Boulay, 'The quarrel between the Carmelite friars and the secular clergy of London, 1464-1468', Journal of Ecclesiastical History, VI, 1955, pp. 156-74.

E. Duffy, 'Devotion to the crucifix and related images in England on the eve of the Reformation', in Bilder und Bildersturm im Spätmittelalter und in der früher Neuzeit, ed. R. Scribner, Wolfenbütteler Forschungen, XLVI, Wiesbaden, 1990, pp. 21-36.

E. Duffy, 'Holy maydens, holy wyfes: the cult of women saints in fifteenth- and sixteenth-century England', Studies in Church History, XXVII, 1990, pp. 175-96.

R. W. Dunning and T. D. Tremlett, eds., Bridgwater Borough Archives, V: 1468-1485, Somerset Record Society, LXX, 1971.

G. R. Elton, England, 1200-1640, London, 1969. 
D. Englander, D. Norman, R. O'Day and W. R. Owens, eds, Culture and Belief in Europe, 1450-1600: an Anthology of Sources, Oxford, 1990.

T. Erbe, ed., Mirk's Festial: a Collection of Homilies by Johannes Mirkus (John Mirk), Early English Text Society, extra ser., XCVI, 1905.

A. M. Erskine, ed., The Accounts of the Fabric of Exeter Cathedral, 1279-1353, Devon and Cornwall Record Society, n.s., XXIV, XXVI, 1981-3.

R. C. Finucane, Miracles and Pilgrims: Popular Beliefs in Medieval England, London, 1977.

P. W. Fleming, 'Charity, faith, and the gentry of Kent, 1422-1529', in Property and Politics: Essays in Later Medieval English History, ed. T. Pollard, Gloucester, 1984, pp. 36-57.

A. J. Fletcher, 'Unnoticed sermons from John Mirk's Festial', Speculum, LV, 1980, pp. 514-22.

A.J. Fletcher, 'John Mirk and the Lollards', Medium Avvum, LVI, 1987, pp. 217-24.

S. Forde, 'Nicholas Hereford's Ascension Day sermon, 1382', Mediaeval Studies, LI, 1989, pp. 205-41.

J. Forshall and F. Madden, eds, The New Testament in English, According to the Version by John Wycliffe, about A.D. 1380, and Revised by John Purvey about A.D. 1388, Oxford, 1879.

D. B. Foss, 'John Mirk's Instructions for parish priests', Studies in Church History, XXVI, 1989, pp. 131-40.

W. H. Frere, 'York service books', in Walter Howard Frere: a Collection of his Papers on Liturgical and Historical Subjects, ed. J. H. Arnold and E. G. P. Wyatt, Alcuin Club Collections, XXXV, 1940, pp. 159-69.

E. A. Fry, 'Dorset chantries', Proceedings of the Dorset Natural History and Antiquarian Field Club, XXVII, 1906, pp. 214-33, XXVIII, 1907, pp. 12-29.

A. Gash, 'Carnival against Lent: the ambivalence of medieval drama', in Medieval Literature: Criticism, Ideology, and History, ed. D. Aers, New York, 1986, pp. 74-98.

G. McM. Gibson, The Theater of Devotion: East Anglian Drama and Society in the Late Middle Ages, Chicago and London, 1989.

V. Gillespie, 'Vernacular books of religion', in Book Production and Publishing in Britain, 1375-1475, ed. J. Griffiths and D. Pearsall, Cambridge, 1989, pp. 317-44.

S. L. Greenslade, 'English versions of the Bible, 1525-1611', in The Cambridge History of the Bible [vol. III]: The World from the Reformation to the Present Day, ed. S. L. Greenslade, Cambridge, 1963, pp. 141-74.

P. Grosjean, ed., Henrici VI Angliae regis miracula postuma, ex Codice Musei Britannici Regio 13.C.VIII, Subsidia Hagiographica, XXII, Brussels, 1935.

P. Gwyn, The King's Cardinal: the Rise and Fall of Thomas Wolsey, London, 1990.

C. Haigh, 'Introduction', in The English Reformation Revised, ed. C. Haigh, Cambridge, 1987, pp. 1-17.

C. Haigh, 'Anticlericalism in the English Reformation', in The English Reformation Revised, ed. C. Haigh, Cambridge, 1987, pp. 56-74.

R. M. Haines, Ecclesia Anglicana: Studies in the English Church of the Later Middle Ages, London and Toronto, 1989.

B. Hamilton, Religion in the Medieval West, London, 1986.

C. Harper-Bill, 'Dean Colet's convocation sermon and the pre-Reformation church in England', History, LXXIII, 1988, pp. 191-210. 
C. Harper-Bill, The Pre-Reformation Church in England, 1400-1530, London and New York, 1989.

F. Ll. Harrison, Music in Medieval Britain, 4th ed., London, 1980.

P. Heath, The English Parish Clergy on the Eve of the Reformation, London and Toronto, 1960.

P. Heath, Medieval Clerical Accounts, St Anthony's Hall Publications, XXVI, York, 1964.

P. Heath, 'Urban piety in the later middle ages: the evidence of Hull wills', in The Church, Politics, and Patronage in the Fifteenth Century, ed. R. B. Dobson, Gloucester, 1984, pp. 209-34.

T. J. Heffernan, 'Sermon literature', in Middle English Prose: a Critical Guide to Major Authors and Genres, ed. A. S. G. Edwards, Brunswick, NJ, 1984, pp. 177-207.

M. Hicks, 'Chantries, obits, and almshouses: the Hungerford foundations', in The Church in Pre-Reformation Society: Essays in Honour of F. R. H. du Boulay, ed. C. M. Barron and C. Harper-Bill, Woodbridge, 1985, pp. 123-42.

M. A. Hicks, 'The piety of Margaret, Lady Hungerford (d.1478)', Journal of Ecclesiastical History, XXXVIII, 1987, pp. 19-38.

Walter Hilton, The Scale of Perfection, trans. G. Sitwell, London, 1953.

J. C. Hirsh, 'Prayer and meditation in late medieval England: MS Bodley 789', Medium Evum, XLVIII, 1979, pp. 55-66.

J. C. Hirsh, 'Margery Kempe', in Middle English Prose: a Critical Guide to Major Authors and Genres, ed. A. S. G. Edwards, New Brunswick, N.J., 1984, pp. 109-19.

J. C. Hirsh, The Revelations of Margery Kempe: Paramystical Practices in Late Medieval England, Medieval and Renaissance Authors, X, Leiden, 1989.

Historical Manuscripts Commission: Report of the Manuscripts of Lord Middleton Preserved at Wollaton Hall, Nottingham, London, 1911.

P. Hodgson, 'Ignorancia sacerdotum: a fifteenth century discourse on the Lambeth constitutions', Review of English Studies, XXIV, 1948, pp. 1-11.

J. Hogg, 'Mount Grace Charterhouse and late medieval English spirituality', in Collectanea Cartusiana, III (= Analecta Cartusiana, LXXXII: iii), Salzburg, 1983, pp. $1-43$.

S. E. Holbrook, 'Margery Kempe and Wynkyn de Worde', in The Medieval Mystical Tradition in England: Exeter Symposium IV. Papers read at Dartington Hall, July 1987, ed. M. Glasscoe, Woodbridge, 1987, pp. 27-46.

A. Hope, 'Lollardy: the stone the builders rejected?', in Protestantism and the National Church in Sixteenth Century England, ed. P. Lake and M. Dowling, London, New York, and Sydney, 1987, pp. 1-35.

C. Horstman, ed., Yorkshire Writers: Richard Rolle of Hampole and his Followers, 2 vols, London, 1895-6.

C. Horstman, ed., Nova Legenda Anglie, as Collected by John of Tynemouth, John Capgrave, and Others, and First Printed, with New Lives, by Wynkyn de Worde, a.d. m d xui, 2 vols, Oxford, 1901.

A. Hudson, 'Wycliffite prose', in Middle English Prose: a Critical Guide to Major Authors and Genres, ed. A. S. G. Edwards, New Brunswick, N.J., 1984, pp. 249-70.

A. Hudson, 'A new look at the Lay folks' catechism', Viator, XVI, 1985, pp. 243-58.

A. Hudson, Lollards and their Books, London and Ronceverte, 1986.

A. Hudson, The Premature Reformation: Wycliffite Texts and Lollard History, Oxford, 1988. 
A. Hudson, 'Lollard book production', in Book Production and Publishing in Britain, 1375-1475, ed. J. Griffiths and D. Pearsall, Cambridge, 1989, pp. 125-42.

A. Hudson and P. Gradon, eds, English Wycliffite Sermons, Oxford, 1983-.

J. Huizinga, The Waning of the Middle Ages, London, 1968.

R. F. Hunnisett, 'The reliability of inquisitions as historical evidence', in The Study of Medieval Records: Essays in Honour of Kathleen Major, ed. D. A. Bullough and R. L. Storey, Oxford, 1971, pp. 206-35.

R. Hutton, 'The local impact of the Tudor Reformations', in The English Reformation Revised, ed. C. Haigh, Cambridge, 1987, pp. 114-38.

The Interpretacyon and Sygnyfycacyon of the Masse, London, 1532.

E. W. Ives, The Common Lawyers of Pre-Reformation England, Cambridge, 1983.

G. M. Jantzen, Julian of Norwich: Mystic and Theologian, London, 1987.

P. S. Jolliffe, A Check-List of Middle English Prose Writings of Spiritual Guidance, Pontifical Institute of Mediaeval Studies, Subsidia Mediaevalia, II, Toronto, 1974.

M. K. Jones and M. G. Underwood, The King's Mother: Lady Margaret Beaufort, Countess of Richmond and Derby, Cambridge, 1992.

E. G. H. Kempson, 'A Shropshire guild at work in Wiltshire', Wiltshire Archaeological and Natural History Magazine, LVII, 1958-60, pp. 50-5.

D. G. Kennedy, Incarnational Element in Hilton's Spirituality, Salzburg Studies in English Literature: Elizabethan and Renaissance Studies, XCII: iii, Salzburg, 1982.

A. J. Kettle, ed., A List of Families in the Archdeaconry of Stafford, 1532-3, Collections for a history of Staffordshire, 4th ser., VIII, 1976.

A. A. King, Liturgies of the Past, London, 1959.

P. King, 'The English cadaver tomb in the late fifteenth century: some indications of a Lancastrian connection', in Dies Illa: Death in the Middle Ages. Proceedings of the 1983 Manchester Colloquium, ed. J. H. M. Taylor, Vinaver Studies in French, I, Liverpool, 1984, pp. 45-57.

J. L. Kirby, ed., Calendar of Inquisitions Post Mortem and Other Analogous Documents Preserved in the Public Record Office; vol. XVIII, 1-6 Henry IV, 1399-1405, London, 1987.

D. Knowles, The Religious Orders in England, 3 vols, Cambridge, 1948-61.

D. Knowles, The English Mystical Tradition, London, 1961.

A. Kreider, English Chantries: the Road to Dissolution, Harvard Historical Studies, XCVII, Cambridge, Mass., and London, 1979.

G. Kristensson, ed., John Mirk's Instructions for Parish Priests, Edited from MS Cotton Claudius A II and Six Other Manuscripts, with Introduction, Notes, and Glossary, Lund Studies in English, XLIX, Lund, 1974.

D. Kunzle, The Early Comic Strip: Narrative Strips and Picture Stories in the European Broadsheet from c.1450 to 1825, Berkeley, Los Angeles and London, 1973.

V. M. Lagorio and R. Bradley, The Fourteenth Century English Mystics: a Comprehensive Annotated Bibliography, New York and London, 1981.

G. I. Langmuir, History, Religion, and Antisemitism, Berkeley, Los Angeles, and Oxford, 1990.

N. A. H. Lawrance, ed., Fasti Parochiales, vol. 3: Deanery of Dickering, Yorkshire Archaeological Society Record Series, CXXIX, 1967.

J. W. Legg, ed., The Processional of the Nuns of Chester, Henry Bradshaw Society, XVIII, 1899. 
J. W. Legg, ed., Tracts on the Mass, Henry Bradshaw Society, XXVII, London, 1904.

L. Lepow, Enacting the Sacrament: Counter-Lollardy in the Towneley cycle, London and Toronto, 1990.

C. Lindberg, ed., The Middle English Bible: The Book of Judges, Oslo, 1989.

H. Littlehales, ed., The Prymer, or Lay Folks' Prayer Book, part 1, Early English Text Society, original ser. CV, 1895.

H. Littlehales, English Fragments from Latin Medieval Service-Books, Early English Text Society, extra ser., XC, 1903.

W. E. Lunt, Financial Relations of the Papacy with England, 1327-1534, Publications of the Mediaeval Academy of America, LXXIV, Cambridge, Mass., 1962.

J. H. Lupton, A Life of John Colet, D.D., Dean of St Paul's and Founder of St Paul's School, London, 1887.

D. MacCulloch, Suffolk and the Tudors: Politics and Religion in an English County, 15001600, Oxford, 1986, pp. 143-6.

J. W. McKenna, 'Popular canonization as political propaganda: the case of Archbishop Scrope', Speculum, XLV, 1970, pp. 608-23.

P. McNiven, Heresy and Politics in the Reign of Henry IV: the Burning of John Badby, Woodbridge, 1987.

B. R. McRee, 'Religious guilds and regulation of behaviour in late medieval towns', in People, Politics, and Community in the Later Middle Ages, ed. J.T. Rosenthal and C. Richmond, Gloucester, 1987, pp. 108-22.

A. R. Malden, ed., The Canonization of Saint Osmund, from the Manuscript Records in the Muniment Room of Salisbury Cathedral, Wiltshire Record Society, II, 1901.

C. A. Martin, 'Middle English manuals of religious instruction', in So Meny People, Longages, and Tonges: Philological Essays in Scots and Mediaeval English Presented to Angus McIntosh, ed. M. Benskin and M. L. Samuels, Edinburgh, 1981, pp. 283-98.

J. Mattingly, 'The medieval parish guilds of Cornwall', Journal of the Royal Institution of Cornwall, n.s., X: iii, 1989, pp. 290-329.

J. E. B. Mayor, ed., The English Works of John Fisher, Bishop of Rochester, Early English Text Society, extra ser., XXVII, 1876.

S. B. Meech, 'John Drury and his English writings', Speculum, IX, 1934, pp. 70-83.

H. Mellick, 'In defence of a fifteenth-century manuscript', Parergon, VIII, April, 1974, pp. $20-4$.

K. Mertes, The English Noble Household, 1250-1600: Good Governance and Politic Rule, Oxford, 1988.

R. G. K. A. Mertes, 'The household as a religious community', in People, Politics, and Community in the Fifteenth Century, ed. J. T. Rosenthal and C. Richmond, Gloucester, 1987, pp. 123-39.

A. Minnis, 'The Cloud of Unknowing and Walter Hilton's Scale of Perfection', in Middle English Prose: a Critical Guide to Major Authors and Genres, ed. A. S. G. Edwards, New Brunswick, N.J., 1984, pp. 61-81.

M. Mitchiner, Medieval Pilgrim and Secular Badges, London, 1986.

J. R. H. Moorman, The Grey Friars in Cambridge, 1225-1538, Cambridge, 1952.

J. A. H. Moran, The Growth of English Schooling, 1340-1538: Learning, Literacy, and Laicization in Pre-Reformation York Diocese, Princeton, N.J., 1985.

A. R. Myers, ed., English Historical Documents, 1327-1485, London, 1969. 
The New English Bible, Oxford and Cambridge, 1970.

N. H. Nicholas, ed., Privy Purse Expenses of Elizabeth of York; Wardrobe Accounts of Edward the Fourth, London, 1830.

J. C. T. Oates, 'Richard Pynson and the Holy Blood of Hailes', The Library, 5th ser., XIII, 1958, pp. 269-77.

M. C. O'Connor, The Art of Dying Well: the Development of the Ars Moriendi, New York, 1942.

R. O'Day, The Debate on the English Reformation, London, 1986.

S. J. Ogilvie-Thomson, ed., Walter Hilton's Mixed Life, Edited from Lambeth Palace MS 472, Salzburg Studies in English Literature: Elizabethan and Renaissance Studies, XCII: xv, Salzburg, 1986.

N. Orme, 'Two saint-bishops of Exeter: James Berkeley and Edmund Lacy', Analecta Bollandiana, CIV, 1986, pp. 403-18.

N. Orme, 'Saint Walter of Cowick', Analecta Bollandiana, CVIII, 1990, pp. 387-93.

D. M. Owen, The Records of the Established Church in England, Excluding Parochial Records, British Records Association: Archives and the User, no. I, 1970.

D. M. Owen, 'Bacon and eggs: Bishop Buckingham and superstition in Lincolnshire', Studies in Church History, VIII, 1972, pp. 139-42.

G. R. Owst, Preaching in Medieval England: an Introduction to Sermon Manuscripts of the Period c.1350-1450, Cambridge, 1926.

G. R. Owst, Literature and Pulpit in Medieval England: a Neglected Chapter in the History of English Letters and of the English People, 2nd ed., Oxford, 1961.

W. A. Pantin, 'Instructions for a devout and literate layman', in Medieval Learning and Literature: Essays Presented to Richard William Hunt, ed. J. J. G. Alexander and M. T. Gibson, Oxford, 1976, pp. 398-422.

D. Pearsall, ed., Studies in the Vernon Manuscript, Woodbridge, 1990.

J. W. Percy, ed., York Memorandum Book BY, Surtees Society Publications, CLXXXVI, 1973.

R. W. Pfaff, New Liturgical Feasts in Later Medieval England, Oxford, 1970.

R. W. Pfaff, 'The English devotion of St Gregory's Trental', Speculum, XLIX, 1974, pp. $75-90$.

O. S. Pickering, 'Brotherton Collection MS. 501: a Middle English anthology reconsidered', Leeds Studies in English, n.s. XXI, 1990, pp. 141-65.

S. Powell, ed., The Advent and Nativity Sermons from a Fifteenth-Century Revision of John Mirk's Festial, Middle English Texts, XIII, Heidelberg, 1981.

S. Powell, 'A new dating of John Mirk's Festial', Notes and Queries, CCXXVII, 1982, pp. $487-9$.

S. Powell, 'Lollards and Lombards: late medieval bogeymen', Medium Avum, LIX, 1990, pp. 133-9.

J. S. Purvis, A Mediaeval Act Book, with Some Account of Ecclesiastical Jurisdiction at York, York, n.d. [1943].

U. M. Radford, 'The wax images found in Exeter cathedral', Antiquaries Journal, XXIX, 1949, pp. 164-8.

J. Raine, ed., The Fabric Rolls of York Minster, with an Appendix of Illustrative Documents, Surtees Society Publications, XXXV, 1858.

The Records of the Northern Convocation, Surtees Society Publications, CXIII, 1907. 
G. Redworth, In Defence of the Church Catholic: the Life of Stephen Gardiner, Oxford, 1990.

V. Reinburg, 'Note on John Bossy, "Prayers"', Transactions of the Royal Historical Society, 6th ser., I, 1991, pp. 148-50.

R. Rex, 'The English campaign against Luther in the 1520s', Transactions of the Royal Historical Society, 5th ser., XXXIX, 1989, pp. 85-106.

S. Reynolds, 'Social mentalities and the case of medieval scepticism', Transactions of the Royal Historical Society, 6th ser., I, 1991, pp. 21-41.

D. E. Rhodes, Studies in Early European Printing and Book-Collecting, London, 1983.

C. Richmond, 'Religion and the fifteenth-century English gentleman', in The Church, Politics, and Patronage in the Fifteenth Century, ed. R. B. Dobson, Gloucester, 1984, pp. 193-208.

C. Richmond, 'The English gentry and religion, c.1500', in Religious Belief and Ecclesiastical Careers in Late Medieval England, ed. C. Harper-Bill, Woodbridge, 1991, pp. 121-50.

J. Ridgard, ed., Medieval Framlingham, Select Documents, 1270-1524, Suffolk Record Society, XXVII, 1985.

W. Riehle, The Middle English Mystics, London, Boston, and Henley, 1981.

R. H. Robbins, 'Popular prayers in middle English verse', Modern Philology, XXXVI, 1938-9, pp. 337-50.

R. H. Robbins, 'Private prayers in middle English verse', Studies in Philology, XXXVI, 1939, pp. $466-75$.

N. Rogers, 'The cult of Prince Edward at Tewkesbury', Transactions of the Bristol and Gloucestershire Archaeological Society, CI, 1983, pp. 187-9.

G. Rosser, 'Communities of parish and guild in late medieval England', in Parish, Church, and People: Local Studies in Lay Religion, 1350-1750, ed. S. J. Wright, London, 1988, pp. 32-55.

G. Rosser, 'Parochial conformity and popular religion in late medieval England', Transactions of the Royal Historical Society, 6th ser., I, 1991, pp. 173-89.

M. Rubin, 'Corpus Christi fraternities and late medieval piety', Studies in Church History, XXIII, 1986, pp. 97-109.

M. Rubin, Charity and Community in Late Medieval Cambridge, Cambridge Studies in Medieval Life and Thought, 4th ser., IV, Cambridge, 1987.

M. Rubin, Corpus Christi: the Eucharist in Late Medieval Culture, Cambridge, 1991.

G. H. Russell, 'Vernacular instruction of the laity in the later middle ages in England: some texts and notes', Journal of Religious History, II, 1962, pp. 98-119.

H. E. Salter, ed., Snappe's Formulary and Other Records, Oxford Historical Society, LXXX, 1924.

A. Saltman, ed., The Cartulary of the Wakebridge Chantries at Crich, Derbyshire Archaeological Society, Record Series, VI, 1976, for 1971.

M. G. Sargent, 'Minor devotional writings', in Middle English Prose: a Critical Guide to Major Authors and Genres, ed. A. S. G. Edwards, New Brunswick, N.J., 1984, pp. $147-75$.

J. J. Scarisbrick, The Reformation and the English People, Oxford, 1984.

M. Sellers, ed., York Memorandum Book, Part II (1388-1493), Surtees Society Publications, CXXV, 1914.

J. Shaw, "The influence of canonical and episcopal reform on popular books of instruction', in The Popular Literature of Medieval England, ed. T. J. Heffernan, 
Tennessee Studies in Literature, XXVIII, Knoxville, Tenn., 1985, pp. 44-60.

P. Sheingorn, 'Appropriating the Holy Kinship: gender and family history', in Interpreting Cultural Symbols: Saint Anne in Late Medieval Society, ed. K. Ashley and P. Sheingorn, Athens, Ga., and London, 1990, pp. 169-98.

P. Sheldrake, Spirituality and History: Questions of Interpretation and Method, London, 1991.

T. F. Simmons, ed., The Lay Folks' Mass Book, Early English Text Society, original ser., LXXI, 1879.

T. Smith, L. T. Smith and L. Brentano, eds, English Gilds, Early English Text Society, original ser., XL, 1870.

C. A. Sneyd, ed., A Relation, or Rather a True Account, of the Island of England, with Sundry Particulars of these People and of the Royal Revenues under King Henry the Seventh, about the Year 1500, Camden Society Publications, 1st ser., XXVII, 1847.

W. C. Sparrow, 'A register of the Palmers Guild of Ludlow in the reign of Henry VII', Transactions of the Shropshire Archaeological and Natural History Society, 1st ser., VII, 1884, pp. 81-126.

B. Spencer, 'Medieval pilgrim badges: some general observations illustrated mainly from English sources', in Rotterdam Papers: a Contribution to Medieval Archaeology, ed. J. G. N. Renaud, Rotterdam, 1968, pp. 137-54.

B. Spencer, 'King Henry of Windsor and the London pilgrim', in Collectanea Londiniensia: Studies in London Archaeology and History Presented to Ralph Merrifield, ed. J. Bird, H. Chapman and J. Clark, London and Middlesex Archaeological Society, Special Papers, II, 1978, pp. 234-64.

U. Stargardt, 'The beguines of Belgium, the Dominican nuns of Germany, and Margery Kempe', in The Popular Literature of Medieval England, ed. T. J. Heffernan, Tennessee Studies in Literature, XXVIII, Knoxville, Tenn., 1985, pp. 277-313.

B. Stock, The Implications of Literacy: Written Language and Models of Interpretation in the Eleventh and Twelfth Centuries, Princeton, N.J., 1983.

B. Stock, Listening for the Text: on the Uses of the Past, Baltimore and London, 1990.

J. Sumption, Pilgrimage: an Image of Mediaeval Religion, London, 1975.

R. N. Swanson, Church and Society in Late Medieval England, Oxford, 1989.

R. N. Swanson, 'Sede vacante administration in the medieval diocese of Carlisle: the accounts of the vacancy of December 1395 to March 1396', Transactions of the Cumberland and Westmorland Antiquarian and Archaeological Society, XC, 1990, pp. 183-94.

R. N. Swanson, 'Problems of the priesthood in pre-Reformation England', English Historical Review, CV, 1990, pp. 845-69.

R. N. Swanson, 'Standards of livings: parochial revenues in pre-Reformation England', in Religious Belief and Ecclesiastical Careers in Late Medieval England, ed. C. HarperBill, Woodbridge, 1991, pp. 151-96.

R. N. Swanson, 'Chaucer's parson and other priests', Studies in the Age of Chaucer, XIII, 1991, pp. 41-80.

R. N. Swanson, 'Medieval liturgy as theatre: the props', Studies in Church History, XXIX, 1992, pp. 239-53.

N. P. Tanner, ed., Heresy Trials in the Diocese of Norwich, 1428-31, Camden Society Publications, 4th ser., XX, 1977.

Testamenta Eboracensia, III, Surtees Society Publications, XLV, 1865. 
Testamenta Eboracensia, IV, Surtees Society Publications, LIII, 1868.

J. A. F. Thomson, The Later Lollards, 1414-1520, Oxford, 1965.

J. A. F. Thomson, The Transformation of Medieval England, 1370-1529, London, 1983.

J. A. F. Thomson, 'Orthodox religion and the origins of Lollardy', History, LXXIV, 1989, pp. 39-55.

The Thornton Manuscript, Lincoln Cathedral MS. 91, introduction by D. S. Brewer and A. E. B. Owen, London, 1975.

R. G. Twombly, 'Remembering death and dismembering the self; 1418, 1440 and after', Journal of Literature and Theology, II, 1989, pp. 189-210.

M. G. A. Vale, Piety, Charity, and Literacy among the Yorkshire Gentry, 1370-1480, Borthwick Papers, L, York, 1976.

A. Vauchez, La saintété en occident des derniers siècles du moyen âge, d'après les procès de canonisation et les documents hagiographiques, Bibliothèque des écoles françaises d'Athènes et de Rome, CCXLI, Rome, 1981.

E. W. W. Veale, ed., The Great Red Book of Bristol, I, Bristol Record Society, IV, 1933.

E. W. W. Veale, ed., The Great Red Book of Bristol, IV, Bristol Record Society, XVIII, 1953.

E. Venables, 'The shrine and head of St Hugh of Lincoln', Associated Architectural Societies Reports and Papers, XXI, 1891-2, pp. 131-51.

The Vernon Manuscript; a Facsimile of Bodleian Library, Oxford, MS. Eng. Poet.a.1, introduction by A. I. Doyle, Cambridge, 1987.

Victoria County History: Shropshire, II, Oxford, 1973.

M. F. Wakelin, 'A note on preaching "roodes and othyr ymages" in mediaeval England', Downside Review, CIII, 1985, pp. 76-86.

S. S. Walker, 'Proof of age of feudal heirs in medieval England', Mediaeval Studies, XXXV, 1973, pp. 306-23.

J. Walsh, Pre-Reformation English Spirituality, London, n.d.

A. K. Warren, Anchorites and their Patrons in Medieval England, Berkeley, Los Angeles and London, 1988.

F. E. Warren, ed., The Sarum Missal in English, Alcuin Club Collections, XI, 2 vols, London, 1913.

R. Weber, ed., Biblia Sacra iuxtra Vulgatam versionem, 2 vols, Stuttgart, 1969.

S. Wenzel, Preachers, Poets, and the Early English Lyric, Princeton, N.J., 1986.

H. F. Westlake, The Parish Guilds of Medieval England, London, 1919.

R. Whiting, The Blind Devotion of the People: Popular Religion and the English Reformation, Cambridge, 1989.

R. S. Wieck, Time Sanctified: the Book of Hours in Medieval Art and Life, New York, 1988.

M. Wilks, 'Misleading manuscripts: Wyclif and the non-Wycliffite Bible', Studies in Church History, XI, 1975, pp. 147-61.

C. H. Williams, ed., English Historical Documents, 1485-1558, London, 1963.

B. L. Windeatt, ed., The Book of Margery Kempe, Harmondsworth, 1985.

C. Wolters, ed., Julian of Norwich, Revelations of Divine Love, Harmondsworth, 1966.

M. Wood, The English Mediaeval House, London, 1981.

K. Wood-Legh, Perpetual Chantries in Britain, Cambridge, 1965. 
K. L. Wood-Legh, Kentish Visitations of Archbishop William Warham and his Deputies, 1511-1512, Kent Records, XXIV, 1984.

C. E. Woodruff, 'The financial aspect of the cult of St Thomas of Canterbury, as recorded by a study of the monastic records', Archaeologia Cantiana, XLIV, 1932, pp. $13-32$.

C. Wordsworth, ed., Ordinale Sarum, sive directorium sacerdotum, Henry Bradshaw Society, XX, XXII, 1901.

D. P. Wright, ed., The Register of Thomas Langton, Bishop of Salisbury, 1485-93, Canterbury and York Society, LXXIV, 1985.

S. K. Wright, 'The provenance and manuscript tradition of the Martyrium Ricardi archiepiscopi, Manuscripta, XXVIII, 1984, pp. 92-102.

S. K. Wright, 'Paradigmatic ambiguities in monastic historiography: the case of Clement Maidstone's Martyrium Ricardi archiepiscopi, Studia Monastica, XXVIII, 1986, pp. 311-42.

M. L. Zell, "The use of religious preambles as a measure of religious belief in the sixteenth century', Bulletin of the Institute of Historical Research, L, 1977, pp. 246-9.

C. Zika, 'Hosts, processions, and pilgrimages in fifteenth-century Germany', Past and Present, CXVIII, Feb. 1988, pp. 25-64. 